\title{
Hepatitis C Virus Core Antigen Test: an HCV RNA screening alternative in end-stage renal disease and hemodialysis?
}

\author{
Rita V Alves ${ }^{1}$, Hernâni Gonçalves ${ }^{1}$, Maria L Gonçalves ${ }^{2}$, Karina Lopes ${ }^{1}$, Flora Sofia ${ }^{1}$, Ana V Lobos ${ }^{1}$ \\ ${ }^{1}$ Nephrology Department, Centro Hospitalar Médio Tejo, Torres Novas, Portugal \\ ${ }^{2}$ Immunohemotherapy Department, Centro Hospitalar Médio Tejo, Torres Novas, Portugal
}

\section{ABSTRACT}

Introduction and Aim: Hepatitis C virus screening using anti-HCV antibody is recommended for end-stage renal disease and chronic hemodialysis patients. Since the anti-HCV antibody test is not able to differentiate a concurrent infection from a resolved past one, a more reliable and cost-effective screening test is needed.

Materials and Methods: Prospective study of end-stage renal disease and chronic hemodialysis patients from a hospital unit who were screened by anti-HCV antibody and total ARCHITECT $^{\circledR}$ HCV antigen assay.

Results: Cohen's k test was run to determine if there was agreement between HCV Ribonucleic Acid and HCV core antigen assays on 7 individuals with positive anti-HCV antibody. The two tests had a perfect measurement agreement.

Conclusions: HCV core antigen testing could be used as a sensitive method for HCV infection screening in this group of patients based on its accuracy, simplicity and low expense.

Key-words: Anti-HCV antibody; Diagnosis; HCV RNA; Infection

\section{INTRODUCTION}

Patients on chronic hemodialysis are at increased risk of Hepatitis $\mathrm{C}$ virus (HCV) infection, which is widely recognized as one of the main causes of acute and chronic hepatitis, cirrhosis, and hepatocellular carcinoma. ${ }^{1-3}$

As the disease is almost always asymptomatic until the very late stages, the diagnosis is often made after a positive screening result for anti-HCV antibody (Ab) for blood donation, high-risk settings, surgical or hospital screenings, following the casual finding of raised alanine aminotransferase (ALT) levels during check-up. ${ }^{4}$

HCV has global public health relevance, as it is endemic worldwide and although there are varying prevalence rates in different regions of the world, it impacts both developed and developing countries. ${ }^{5}$ In 2017, the Portuguese National Program for Viral Hepatitis Report estimated a $1.1 \%$ prevalence for HCV infection. ${ }^{6}$

$\mathrm{HCV}$ is both a cause and a consequence of renal impairment: it may induce renal disease and has a higher prevalence among chronic kidney disease (CKD) subjects undergoing hemodialysis than in the general population due to medical procedures and is mainly related to parenteral exposure. ${ }^{2,3,7}$ Since the $\mathrm{HCV}$ is transmitted primarily through percutaneous blood exposure ${ }^{7}$, the number of years spent on dialysis therapy has been identified as an independent risk factor for HCV infection in hemodialysis patients. ${ }^{8}$ There is a window period between acute infection and antibody production that may be more prolonged in those patients due to the immunodeficiency state. ${ }^{1,9}$ In
Portugal, in 2016, there were 293 cases of chronic infection in hemodialysis patients, treated or in treatment. ${ }^{5}$.

According to the current international guidelines, CKD patients ever treated by hemodialysis are recommended to be screened for HCV infection ${ }^{11}$, starting with the search for anti-HCV antibodies both for screening and clinical diagnosis of an HCV infection. ${ }^{12,13}$

The Portuguese Doctors Society 2017 Chronic Dialysis Good Practice Manual also recommends the screening of all hemodialysis patients using anti-HCV Ab on admission, readmission and, if negative, biannually. Table 1 explains the screening algorithm proposed in those guidelines. ${ }^{11}$

Diagnostic assays for HCV may be categorized into (a) first-level (enzyme immunoassays with different format) and second-level

\section{Table 1}

Screening algorithm for HCV in hemodialysis patients in 2017 - Chronic Dialysis Good Practice Manual. ${ }^{11}$

\begin{tabular}{c|c||c}
$\begin{array}{c}\text { Anti-HCV+ } \mathbf{A b}^{\dagger} \\
\text { on admission }\end{array}$ & & \multicolumn{1}{c}{ Notes } \\
\hline Negative & $\begin{array}{c}\text { Test again on readmissions } \\
\text { and every 6 months }\end{array}$ & \\
Positive & Test for HCV RNA ${ }^{\dagger}$ & - HCV RNA negative: test every 6 \\
& & $\begin{array}{l}\text { months } \\
\end{array}$ \\
& & - HCV RNA positive: test every 12 \\
& months
\end{tabular}

† Ab-Antibody; HCV - Hepatitis C Virus; RNA - Ribonucleic Acid 
(immunoblot) serological assays for HCV antibodies, which detect the host immune response to an ongoing or past infection; and (b) virological assays where an active infection is identified by detecting HCV RNA or, more recently, the HCV core antigen $(\mathrm{Ag}){ }^{4}$

The diagnostic limitation of antibody assays is that a positive result will not distinguish the stage of HCV infection (inactive, or whether acute or chronic if active); it only indicates a previous exposure to $\mathrm{HCV}^{2,14}$ For this purpose, direct viral assays such as HCV-RNA are needed. Furthermore, by analyzing the presence of anti-HCV antibodies in a general population at an unknown risk, it is fairly common to detect low-level anti-HCV Ab positivity, with no definite classification by the additional tests. This analysis, which currently uses highly sensitive methods, requires the use of specific technology such as Polymerase Chain Reaction (PCR) or other RNA amplification methods and instrumentation, and the availability of a further sample or withdrawal with a time of response that can amount to several days. ${ }^{4,12}$

Like HCV-RNA, HCV Ag is also detected in the serum or plasma long before antibodies to HCV: the antibody window can be extended up to 12 weeks, whereas HCV Ag is usually detectable within 2-3 weeks of infection, almost simultaneously with HCV-RNA detection with molecular biology techniques. ${ }^{15} \mathrm{~A}$ positive result for $\mathrm{HCV}$ Ag will confirm the viral replication activity. ${ }^{4}$

ARCHITECT ${ }^{\circledR}$ HCV Antigen assay is a chemiluminescent microparticle immunoassay for the quantitative determination of core antigen of the HCV in human serum and plasma which employs microparticles coated with anti-HCV monoclonal antibodies that capture the HCV core Ag. The assay can be performed on the same sample and with the same instrumentation used for antibody detection. A running time of only 30 min for a single test allows high throughput and a quick clinical response. In some studies, the test demonstrated a specificity of $\geq 99.5 \%$ and a sensitivity of $\leq 3.00 \mathrm{fmol} / \mathrm{L}^{16}$

The overall cost, high technical skill requirement and long incubation time limit the applicability of direct viral detection methods, such as PCR, for mass screening of HCV infection. Therefore, the next technological development must replace the existing technology with a faster, more reliable and equally accurate analysis, while employing ubiquitous technology and consequently highly reducing costs. ${ }^{14,17,18}$

\section{MATERIAL AND METHODS}

We performed a prospective study of patients with CKD stage 5 or on hemodialysis in the Centro Hospitalar do Médio Tejo hemodialysis unit between March and August of 2017. Patients were screened by anti-HCV Ab and total ARCHITECT ${ }^{\circledR}$ HCV Antigen assay and those with one or both positive results were submitted to real time PCR for determination of the virus and viral load quantification.

Four milliliters of blood were collected in a tube by venipuncture from each patient in EDTA-treated or dry-plasma tubes, immediately centrifuged for serum separation and transferred to the immunohemotherapy lab.
All samples were tested for $\mathrm{HBs} \mathrm{Ag}$, anti-HCV Ab and HCV core $\mathrm{Ag}$ assay, using Abbot ARCHITECT ${ }^{\circledR}$ 2000iSR, a chemiluminescence immunoassay, according to the instructions provided by the manufacturer. The positive samples for anti-HCV Ab were also tested for HCV-RNA using Abbott m24sp for extraction and Abbott m2000 RealTime System for amplification.

Patient charts and documents were reviewed by the investigator. Data collected comprised demographic information, renal disease etiology and viral status.

Statistical analysis was performed using SPSS version 23 for Mac OS X (version 23.0, SPSS, Chicago, III., USA). Categorical variables are presented as frequencies and percentages, and continuous variables as means and standard deviations. All reported P values are two-tailed, with a $P$ value of 0.05 indicating statistical significance.

The sensitivity and specificity of the HCV core Ag test were calculated according to the standard formula. Cohen's $\mathrm{K}$ test was run to determine if there was agreement between HCV RNA and HCV core $\mathrm{Ag}$ assays.

\section{RESULTS}

Seventy-seven patients with CKD stage 5 or on chronic hemodialysis were analyzed in this prospective study. The majority of the patients $(67.5 \%)$ were males and the mean age was 72.7314 .05 years, ranging from 23 to 101 years. Sixty-seven (87\%) were on hemodialysis and the duration of hemodialysis was $24.87 \pm 32.48$ months, ranging from 1 to 235 months. Patients demographic data and characteristics are presented in Table 2.

From the total sample of 77 patients, 70 (90.9\%) had anti-HCV Ab negative serum samples, and the same patients had also HCV core $\mathrm{Ag}$ negative. The rate of HCV infection among HCV Ab negative hemodialysis patients was null.

The 7 patients that had a positive Anti-HCV Ab were subjected to HCV core Ag followed by HCV RNA, of which two males (2.6\%) were positive in both tests. The first male had CKD stage 5 , was 54 years old, had $45.53 \mathrm{fmol} / \mathrm{L}$ of HCV core Ag and $1124930 \mathrm{IU} / \mathrm{mL}$ HCV RNA copies, while the second male had one month of hemodialysis, was 89 years old, had $471.38 \mathrm{fmol} / \mathrm{L}$ of HCV core Ag and $98550 \mathrm{IU} / \mathrm{mL} \mathrm{HCV}$ RNA copies.

No HCV core Ag positive with negative Anti-HCV Ab patients were found, so it was not possible to calculate the seroconversion time window.

Despite the small sample size, it was decided to run a Cohen's $\mathrm{K}$ test to determine if there was agreement between HCV RNA and HCV core Antigen assays on 7 individuals with positive Anti-HCV Ab. The two tests had a perfect measurement agreement (Kappa 1, p<0.008). Comparing the HCV core Ag analysis with real time PCR for HCV RNA measurement, considered gold standard for HCV infection determination in this patient population, there were no false negatives or false positives and sensitivity and specificity were $100 \%$ for this sample. 


\section{Table 2}

Demographic Characteristics of the Patients

\begin{tabular}{|c|c|}
\hline \multicolumn{2}{|c|}{ General characterization $(n=77)$} \\
\hline Mean age $\pm S D_{\ddagger}\left(y r_{\ddagger}\right)$ & $72.73 \pm 14.05$ \\
\hline Male sex - no. $\ddagger(\%)$ & $52(67 \%)$ \\
\hline Hemodialysis - no. (\%) & $67(87 \%)$ \\
\hline Mean time on hemodialysis \pm SD (months) & $24.87 \pm 32.48$ \\
\hline Positive Anti-HCV $\neq \mathrm{Ab} \ddagger$ & $7(9,1 \%)$ \\
\hline Positive HCV core antigen & $2(2.6 \%)$ \\
\hline Previous HCV treatment - no. (\%) & $3(3.9 \%)$ \\
\hline HBs‡ Antigen positive - no. (\%) & $2(2.6 \%)$ \\
\hline HBs Ab positive - no. (\%) & $22(28.6 \%)$ \\
\hline $\mathrm{HBc}$ total $\mathrm{Ab} \neq$ positive - no. $(\%)$ & $8(10.4 \%)$ \\
\hline $\mathrm{HIV}_{\ddagger} 1 / 2 \mathrm{Ab}$ positive - no. $(\%)$ & $0(0 \%)$ \\
\hline \multicolumn{2}{|c|}{ HCV RNA $\ddagger(n=7)$} \\
\hline Undetectable - no. (\%) & $5(71.4 \%)$ \\
\hline Detectable - no. (\%) & $2(28.5 \%)$ \\
\hline \multicolumn{2}{|c|}{$C K D_{\ddagger}$ etiology $(n=77)$} \\
\hline Cardio-renal Syndrome - no. (\%) & $9(11.7 \%)$ \\
\hline$A D P K D_{\ddagger}-$ no. $(\%)$ & $3(3.9 \%)$ \\
\hline Chronic Glomerulonephritis - no. (\%) & $3(3.9 \%)$ \\
\hline Multiple Myeloma - no. (\%) & $4(5.2 \%)$ \\
\hline Hypertensive Nephroangiosclerosis - no. (\%) & $4(5.2 \%)$ \\
\hline Diabetic Nephropathy - no. (\%) & $21(27.3 \%)$ \\
\hline Chronic Pyelonephritis - no. (\%) & $5(6.5 \%)$ \\
\hline Vasculitis - no. (\%) & $3(3.9 \%)$ \\
\hline Others - no. (\%) & $2(2.6 \%)$ \\
\hline Undetermined - no. (\%) & $23(29.9 \%)$ \\
\hline
\end{tabular}

¥ Ab - Antibody; ADPKD - Autosomal Dominant Polycystic Kidney Disease; CKD - Chronic kidney disease; HB - Hepatitis B; HCV - Hepatitis C Virus; HIV - Human Immunodeficiency virus; no. - number; SD - Standard Deviation; $y r$ - years

\section{DISCUSSION}

One limitation of the earlier HCV core Ag assays was the lower sensitivity compared to HCV RNA assays. Currently, the sensitivity of the available HCV core antigen assay, by Abbott, has been improved to about $3.00 \mathrm{fmol} / \mathrm{L}(0.06 \mathrm{pg} / \mathrm{mL}){ }^{12}$

An HCV core Ag assay can be useful in an HCV infection diagnostic algorithm with this newer, more sensitive, assay, especially in a dialysis population that requires frequent screenings due to its high risk condition. ${ }^{12}$ Some papers focusing on dialysis patients showed that a number of anti-HCV negative patients could be identified as infected by HCV with a positive HCV core Ag assay. 5,15

The use of this test will depend on the potential for cost saving in the diagnostic of HCV infection in a population setting. Thus, anti-HCV positive results would be reflexed to $\mathrm{HCV}$ core Ag testing, and additional HCV RNA testing would only be required if HCV core Ag was negative, and potential confirmation of anti-HCV with Recombinant ImmunoBlot Assay (RIBA) would only be necessary when both HCV core antigen and HCV RNA were negative. ${ }^{12}$ This sequential approach (antibody, antigen and RNA) is also beneficial from a cost-effective perspective ${ }^{19,20}$, ensuring the best relationship between invested resources and identification of subjects with active infection over the conventional approach of testing for antibodies and then for HCV-RNA. ${ }^{4}$

Concerning sensitivity, in dialysis patients the search for HCV core Ag instead of HCV-RNA has proven effective to verify HCV incidence ${ }^{4,15}$ : in one study, where all dialysis patients were individually tested for HCV RNA, only one HCV RNA positive patient was found to be $\mathrm{HCV}$ core Ag negative; however, this response could have been caused by the low HCV viral load of HCV RNA $<100 \mathrm{IU} / \mathrm{mL}$ that was verified. $^{5}$

Accurate diagnosis of asymptomatic HCV infection is critical not only to reduce the rates of $\mathrm{HCV}$-associated morbidity and mortality, but also to reduce the chances of nosocomial transmission. ${ }^{16}$

Antibody spread through hemodialysis devices is one of the main reasons to look for a simple and reliable diagnostic method for HCV infection, even before anti-HCV Ab production in this population of patients, as a critical step for the control of infection spread in hemodialysis units. ${ }^{4}$

The positive results verified after testing with HCV core Ag substantiate the authors' opinion that using this test as a screening tool paired with anti-HCV Ab is a cost-effective and reliable test for hepatitis $C$ detection and control. As previously stated, hemodialysis patients perform an HCV screening at least two-times a year. Every time a positive anti-HCV Ab result is found, an expensive and prolonged HCV-RNA test has to be performed; these patients also have to undergo hemodialysis in a dedicated machine while waiting for this result, something which is time and resource-consuming for the hemodialysis unit. As was demonstrated, the HCV core Ag assay had a perfect measurement agreement when compared with HCVRNA, and its sensitivity and specificity were $100 \%$ in a 30 -minute test, which is even superior to the manufacturer's indications. The results make us confident that, with future routine use in our hemodialysis unit, patients can be referred to infectiology earlier when required.

Unfortunately, we did not have any HCV core Ag positive with negative Anti-HCV Ab, so we could not calculate the seroconversion time window and acquire any experience in this topic.

Moini et al presented similar results to the ones presented in this paper and formed the same opinion: HCV core Ag testing can be used as a sensitive method for HCV infection screening in hemodialysis and end-stageend-stage renal disease patients. ${ }^{1}$

In conclusion, in this study we establish, by comparing immunoassay methods for HCV core Ag detection with the gold standard (RT-PCR for detection of HCV RNA), that the HCV core Ag detection test could be used as an effective screening test in patients on hemodialysis based on its accuracy, simplicity and low expense. However, due to our small sample size, further studies should be performed to improve the robustness of the data. The bibliographic research found other papers that corroborate our findings and impressions with HCV core Ag detection tests. ${ }^{14,17,18,21-23}$ 


\section{Acknowledgments}

We would like to thank $\mathrm{Abbott}^{\circledR}$ for providing the $\mathrm{HCV}$ core antigen kits.

Disclosure of potential conflicts of interest: none declared.

\section{References}

1. Moini M, Ziyaeyan M, Aghaei S, Sagheb MM, Taghavi SA, Moeini M, et al. Hepatitis C virus (HCV) infection rate among seronegative hemodialysis patients screened by two methods; HCV core antigen and polymerase chain reaction. Hepat Mon. 2013;13(6):1-6.

2. Fabrizi F, De Vecchi AF, Como G, Lunghi G, Martin P. De novo HCV infection among dialysis patients: A prospective study by HCV core antigen ELISA assay. Aliment Pharmacol Ther. 2005;21(7):861-9.

3. Ko SY, Choe WH. Management of hepatitis C viral infection in chronic kidney disease patients on hemodialysis in the era of direct-acting antivirals. Clin Mol Hepatol. 2018; 24(4):351-357;

4. Galli C, Julicher P, Plebani M. HCV core antigen comes of age : a new opportunity for the diagnosis of hepatitis C virus infection HCVAg assay. Clin Chem Lab Med. 2018;56(6):880-8.

5. Padua E, Avo AP, Almeida C, Agua Doce I, Cortes Martins H. Assessment of Hepatitis C Virus Diversity in Addition to the Frequency of Genotypes in Samples Analyzed Between 2009 and 2014 at the Reference Laboratory of National Health Institute Dr. Ricardo Jorge. Acta Med Port. 2015;28(6):695-701.

6. Direção-Geral da Saúde. Programa nacional para as hepatites virais 2017. 2017.

7. Kao HH, Chen KS, Lin CL, Chang JJ, Lee CH. Utilization of Signal-to-Cutoff Ratio of Hepatitis C Virus Antibody Assay in Predicting HCV Viremia among Hemodialysis Patients. Nephron. 2015;130(2):127-33.

8. Patel PR, Thompson ND, Kallen AJ, Arduino MJ. Epidemiology, surveillance, and prevention of hepatitis C virus infections in hemodialysis patients. Am J Kidney Dis [Internet]. 2010;56(2):3718. Available from: http://dx.doi.org/10.1053/j.ajkd.2010.01.025

9. Niu MT, Coleman PJ AM. Multicenter study of hepatitis C virus infection in chronic hemodialysis patients and hemodialysis center staff members. Am J Kidney Dis. 1993;22:568-73.

10. Li D, Zhu S, Wang T, An J, Wang L, Tao C. Comparison of Elecsys Anti-HCV II Assay With Other HCV Screening Assays. J Clin Lab Anal. 2016;30(5):451-6.

11. Médicos $\mathrm{O}$ dos. Manual de Boas Práticas de Diálise Crónica da Ordem dos Médicos Edição de 2017. 2017.

12. Centers for Disease Control and Prevention. Testing for HCV Infection: An Update of Guidance for Clinicians and Laboratories. Morb Mortal Wkly Rep [Internet]. 2013;62(18):362-5. Available from: http://www.ncbi.nlm.nih.gov/pubmed/23657108
13. Geddes C, Lindley E, Duncan N. Renal Association Clinical Practice Guideline on prevention of blood borne virus infection in the renal unit. Nephron Clin Pr. 2011;118:c165-88.

14. Bouzgarrou N, Fodha I, Ben Othman S, Achour A, Grattard F, Trabelsi A, et al. Evaluation of a total core antigen assay for the diagnosis of hepatitis $\mathrm{C}$ virus infection in hemodialysis patients. J Med Virol. 2005;77(4):502-8.

15. Tillmann HL. Hepatitis C virus core antigen testing: Role in diagnosis, disease monitoring and treatment. World J Gastroenterol. 2014;20(22):6701-6.

16. Miedouge M, Saune K, Kamar N, Rieu M, Rostaing L, Izopet J. Analytical evaluation of HCV core antigen and interest for HCV screening in haemodialysis patients. J Clin Virol [Internet]. 2010;48(1):18-21. Available from: http://dx.doi.org/10.1016/j.jcv.2010.02.012

17. AK Reddy, KV D Murthy VL. Prevalence of HCV Infection in Patients on Haemodialysis: Survey by Antibody and Core Antigen Detection AK. Indian J Med Microbiol. 2005;23(2):106-10.

18. Medhi S, Potukuchi SK, Polipalli SK, Swargiary SS, Deka P, Choudhary A, et al. Diagnostic utility of hepatitis C virus core antigen in hemodialysis patients. Clin Biochem. 2008;41(7-8):447-52.

19. Reyes-Méndez MÁ, Juárez-Figueroa L, Iracheta-Hernández $P$, Medina-Islas $Y$, Ruiz-González V. Comparison of two diagnostic algorithms for the identification of patients with HCV Viremia using a new HCV antigen test. Ann Hepatol. 2014;13(3):337-42.

20. Kadkhoda K SG. HCV antigen testing for the diagnosis of hepatitis $C$ infection: a cost-efficient algorithm. Clin Lab. 2014;60:677-80.

21. Fabrizi F, Lunghi G, Aucella F, Mangano S, Barbisoni F, Bisegna S, et al. Novel Assay Using Total Hepatitis C Virus (HCV) Core Antigen quantification for Diagnosis of HCV Infection in Dialysis Patients. J Clin Microbiol. 2005;43(1):414-20.

22. Wafaa M. El-Emshaty, Douaa Raafat, Doaa M. Elghannam, Niveen Saudy, Ehab E. Eltoraby AEAM. Diagnostic performance of an immunoassay for simultaneous detection of hcv core antigen and antibodies among haemodialysis patients. Braz J Microbiol. 2011;42:303-9.

23. Li Cavoli G, Zagarrigo C, Schillaci O, Servillo F, Tralongo A, Coglitore M, et al. Hepatitis C virus core antigen test in monitoring of dialysis patients. Hepat Res Treat [Internet]. 2012;2012:832021. Available from: http://www.pubmedcentral.nih.gov/articlerender.fcgi?artid=3523129\&tool=pmc entrez\&rendertype=abstract

\section{Correspondence to:}

Rita Valério Alves, MD

Nephrology Department, Centro Hospitalar Médio Tejo

Av. Dr. Xanana Gusmão, 45. 2350-754 Torres Novas. PORTUGAL

Phone number: +351249810100

E-mail: anarita1990@gmail.com 